\title{
NEW APPARATUS TO RAISE THE PERFORMANCE OF ENGINE COOLING WATER CYCLE
}

\section{EL-Shabrawy T. H.*}

\begin{abstract}
\end{abstract}
Internal combustion engines consider as a power source of all machines in agricultural operations. To obtain the optimum performance of these engines there temperature must be maintained at the optimum level. To achieve the previous aim, the engine cooling system must be responsible for the absorption of excess heat from the engines particularly in hot regions. Therefore, this study was conducted in order to solve a problem of failure engine water cooling cycle in warm areas by appending an additional unit to the engine cooling water circuit consisting of an additional thermally insulated tank of water cooled by two pieces of peltier sheets and electric cooling fans. When engine temperature rise above the allowed level, the cooling water path throw the assistant cooling apparatus (peltier cooling unit) to maintain the engine temperature at the ideal level. Four main parameters were taken in this study, five levels of electric current intensity CI (1, 2, 3, 4 and 5 Ampere), four levels of water flow rate $\boldsymbol{F R}(0.5,1,1.5$ and 2 liter/min.), four levels of temperature of inlet water $\boldsymbol{W T}\left(75^{\circ}, 80^{\circ}, 85^{\circ}\right.$ and $\left.90^{\circ} \mathrm{C}\right)$, and two types of flow water $\boldsymbol{F T}$ (free flow and in serpentine).

Absorbed heat energy $Q=\mathbf{k J} / \mathbf{m i n}$ was calculated at different levels of studied parameters under study. The obtained results showed that, the peltier sheets with second type of flow water (in serpentine) gained an effective decrease in water temperature, this condition decreased with the increase of inlet water temperature $\boldsymbol{W T}$ above $85^{\circ} \mathrm{C}$. The highest value of absorbed heat energy $Q$ $=502.2 \mathrm{~kJ} / \mathrm{min}$ was gained with $\left(C I_{5}=5 \mathrm{amp}.\right),\left(F R_{4}=2 \mathrm{lit} / \mathrm{min}\right.$. $)$ and $\left(W T_{1}=\right.$ $\left.75^{\circ}\right)$ at serpentine type of flow water rate $\left(F T_{1}\right)$.

\section{INTRODUCTION}

quick approach to internal combustion engines radiator cooling system with its mechanical parts and reported that the temperature drop through the radiator, as a temperature potential equal to the difference in temperature between the average water temperature and the inlet air temperature.

\section{*Lec. Agric. Eng. Dept., Fac. Agric. Mansoura Univ.}


Thus, the rate of heat dissipation from a radiator depends on the difference between the mean fluid or coolant (average coolant temperature) and the surrounding air temperature, (ambient air temperature) Tonye et al. ( 2013). Most internal combustion engines are fluid cooled using either air or a liquid coolant run through a heat exchanger (radiator) cooled by air Gogineni et al. (2014) also in air cooling system reported that, heat is carried away by the flowing over and around the cylinder. Here fins are cast on the cylinder head and cylinder barrel which provide additional conductive and radiating surface, in water-cooling system of cooling engines, the cylinder walls and heads are provided with jacket through which the cooling liquid can circulate. If the external heat couldn't removed damage would be occurred. Valves would burn and warp, lubricating oil would break down, pistons and bearing would overheat and size, the engine would soon stop. Wusner et al. (2009), prepared a model which explains processes within internal combustion engines and prepared a mathematical model of the link between them. Heywood (1988), reported that heat transfer in internal combustion engines is considered to be an important feature of the engines, because of its effect on the engine performance and emissions so , the cooling process is necessary in the engine. Mirko Bovo (2014) in his $\mathrm{PhD}$ thesis studied the bad influence on the body of the engine due to higher temperature results from failure or malfunction lubrication cycle, engine cooling cycle, and during his studies explained the importance of the entry into force of both liquid cooling and lubrication to engine performance rate. Abdelghaffar et al. (2002) studied the effects of coolant temperature on the performance and emissions of a diesel engine and found an inverse relationship between the degree of increase of the engine coolant temperature and the performance of the engine and also the consumption of fuel and therefore carbon dioxide emissions. Pang et al. (2004) mentioned that, different coolant flow strategies have been used in an attempt to improve system efficiency. He concluded that, reverse cooling involves pumping coolant through the head and then through the block as opposed to the conventional system has the advantage of colder coolant in the head which improves heat transfer by nature of a higher temperature difference and reduces heat transfer in the 
block which can therefore be kept at a higher temperature. There are issues in allowing bubbles to escape which will naturally sit at the top of the engine. In the other hand, conventional engine cooling systems are not designed to operate under extreme conditions (uphill trailer tow) and as such are operating excessively at most other driving conditions. For example, in the case of motorway driving, the engine speed is high causing high coolant pump loads; however, due to the high speed of the vehicle, a large cooling power is available over the vehicle radiator match with Brace (2001). Chalgren (2004) mentioned that, conventional cooling systems are passive systems where a mechanical pump is directly linked to the engine and the pumping power is directly linked to the engine speed. A wax element thermostat reacts to top hose coolant temperature and distributes flow accordingly either through the radiator or straight back into the engine without significant cooling. Many applications have attempted to introduce active control, the most common being replacing the mechanical pump and wax element thermostat with an electric pump and an electronic valve. Couetouse and Gentile (1992) developed a control system around an electric coolant pump, electric control valve and shutters to control airflow over the radiator. By measuring inlet manifold pressure and engine temperature to estimate engine power, two coolant temperature set points were defined as $115^{\circ} \mathrm{C}$ at low load and $100^{\circ} \mathrm{C}$ at high load. The coolant temperature was sensed at heater inlet (which would be equivalent to engine out temperature if heat losses in the pipes of radiator are neglected). The present study aims to solve the problem of failure engine water cooling cycle in warm areas by attending on additional unit to the engine cooling water circuit for maintaining the engine temperature at the ideal level.

\section{MATERIALS AND METHODS}

The laboratory experiments were carried out to tested and evaluate the performance of a developed small apparatus which can be provided with the main engine cooling water system to make it more efficient particularly in the warm climate.

The developed apparatus consists of a small thermal electric cooling circuit (T.E.C) attached to a cooling unit consists of two cooling fans provided with scaled thermally insulated water tank (2 liter capacity), a 
water pump and two hoses for water inlet and outlet attached with a manual operated valve as shown in figure (1)

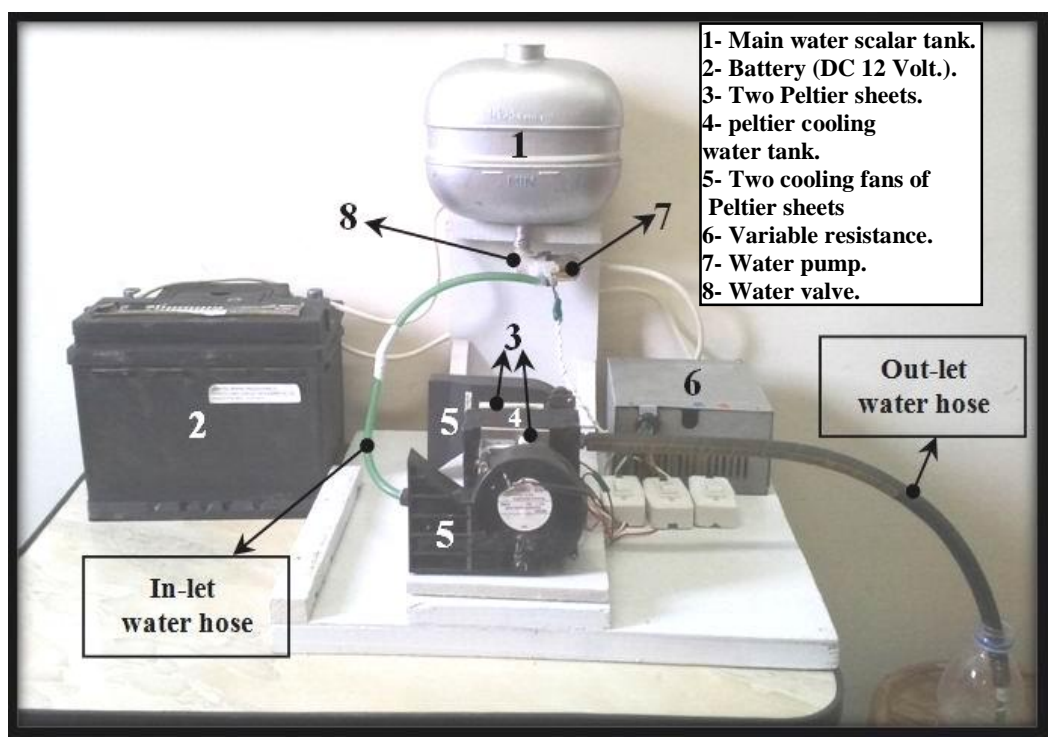

Fig. (1): Experimental unit of (T.E.C)

\section{Source of power:}

A battery (DC 12 Volt.) was used as the main source of electric power for the cooling fans, water pump and peltier sheets). A variable resistance was successively connect to the peltier sheet electric circle to change the connecting current intensity as shown in figure (2A)

Clamp meter device was used to confirm the electric current intensity as shown in figure (2B).

For the possibility of using peltier sheets in the engine cooling system variable resistors was used to reduce electricity current intensity (CI Ampere) with battery (DC 12 Volt).

\section{- Experimental procedure:}

First step: Main isolated thermal water tank (2 liter capacity) was filled with water at the experimental thermal degree (WT ${ }^{\circ} \mathrm{C}$ ) under study.

Second step: To control the intensity of the electric current connecting to peltier sheets, variable resistances (reostate) successively connected to the peltier electric circle to control the current intensity (CI Ampere) under study. 


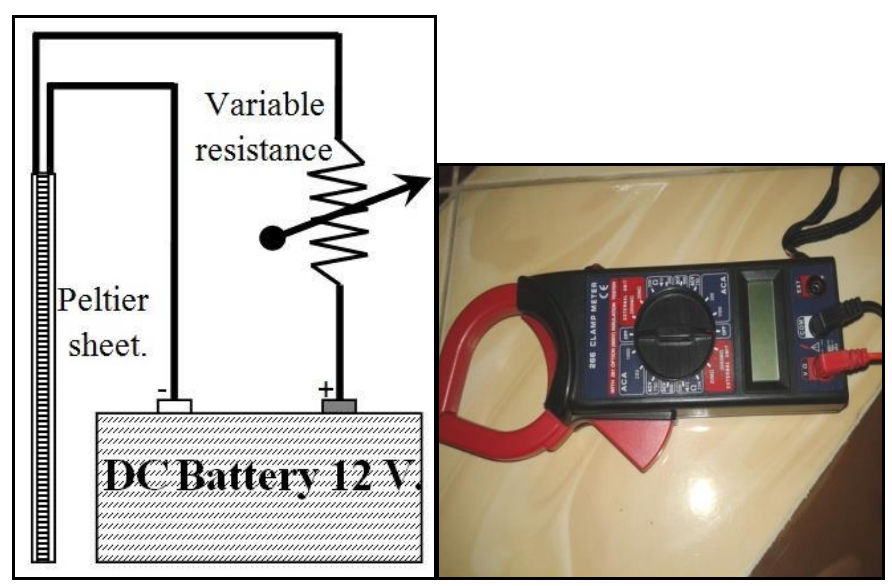

Fig. (2A): Electric peltier circle. Fig. (2B): Clamp meter device.

Third step: Water pump was used to move hot water from the main water tank to the peltier cooling unit, and the manual valve was adjusted to control water flow rate through the peltier cooling unit (FR liter/min).

Fourth step: The out-let water temperature was estimated by thermometer after each experimental run. By knowing (in-let water temperature $\left(\mathrm{WT}{ }^{\circ} \mathrm{C}\right)$, water specific heat $(4.18 \mathrm{~kJ} / \mathrm{kg})$ and Water flow rate $(\mathrm{FR}$ liter./min)), the absorbed heat energy ( $\mathrm{Q} \mathrm{kJ} / \mathrm{min}$ ) was calculated as the main result in this research.

Absorbed heat energy (Q) as $\mathrm{kJ} / \mathrm{min}$. was estimated by following equation:

Where:

$$
\mathrm{Q}=\mathrm{m} \times \mathrm{C}_{\mathrm{p}} \times(\Delta \mathrm{T})={ }^{\mathrm{K}} \mathrm{J} / \mathrm{min} .
$$

$$
\begin{aligned}
& \mathrm{m}=\text { Water flow rate } \mathrm{kg} / \mathrm{min} \text { (water density }=1 \mathrm{~kg} / \mathrm{lit} .) . \\
& \mathrm{C}_{\mathrm{p}}=\text { Water specific heat }=1 \mathrm{Kcal} . / \mathrm{kg}=4.18 \mathrm{~kJ} / \mathrm{kg} . \\
& \Delta \mathrm{T}=\text { Inlet water temperature }- \text { outlet water temperature }(\mathrm{C}) .
\end{aligned}
$$

\section{- Points taken into consideration when manufacturing the cooling unit:}

Important points had been taken into consideration when designing and manufacturing the cooling unit to achieve high efficiency cooling water process as follow:

1- A simple design does not occupy a large space.

2- Simple and easy connections jaw and maintenance.

3- Simple power source (12-Volt battery). 


\section{Thermo-Electric Cooling unit (T.E.C) components}

The thermo-electric cooling system (T.E.C) available in the market and used in wide scale for cooling water apparates (coolders) provided with (T.E.C) sheet with electric energy (DC). One face of the (T.E.C) sheet act for cooling and the other act for warming. The differences in temperature between the two faces dependeing on electric current intensity and sheet surface area. The temperature variation between the (T.E.C) two faces can achive $70^{\circ} \mathrm{C}$ on high estimation. The developed (T.E.C) cooling unit shown in figure (3) can be attached to the main engine cooling cycle by two hoses. The ability to cooling water in the small tank of the unit adjacent to coold surfaces of the peltier sheets causes, the hot surface of sheets constantly cooled by (DC fans) expel hot air to the surrounding area.

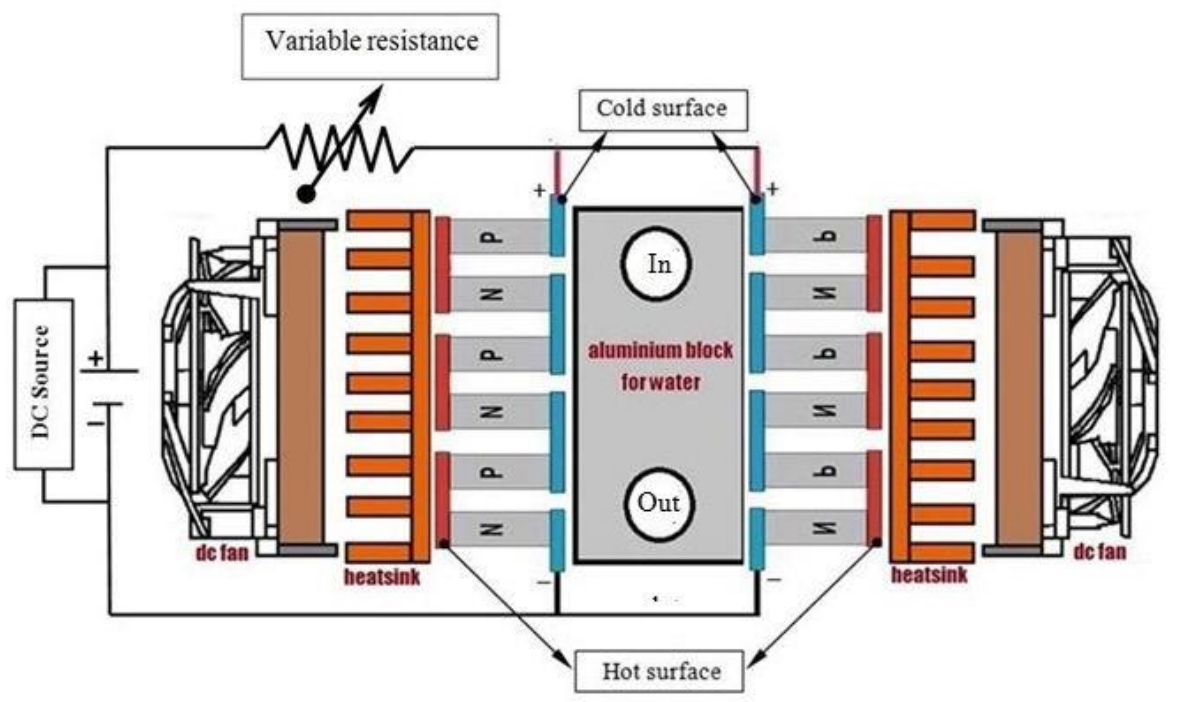

Fig. (3): Thermo-electric cooling unit (T.E.C) components

Two models are manufactured to study the effect of water flow type (FT) inside the (T.E.C) unit on the cooling efficiency (absorbed heat energy).Two peltier sheets with the same dimensions $(50 \times 50 \times 3.6 \mathrm{~mm})$ formed two walls (one opposite the other) inside peltier tank. The peltier tank has parallelogram shape with dimentions $(100 \times 50 \times 50 \mathrm{~mm})$. The peltier tank has two holes, two plastic hose were inserted in the tank holes, the high hose was to assigned to enter the warm water inside the tank and the low hose to drain the cooled wateras shown in figure (4 A and B) 


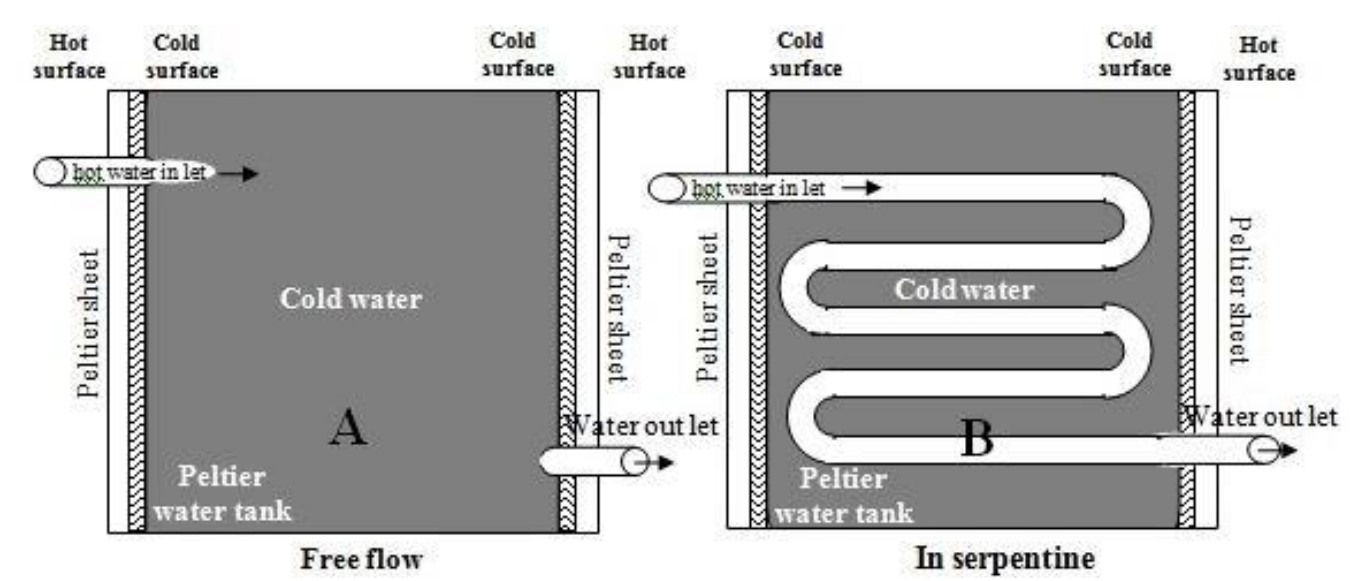

Fig. (4): Two models of thermo-Electric Cooling (T.E.C) tank

\section{Peltier theory}

When DC voltage is applied to the Peltier panels, the positive and negative charge carries in the array, absorb heat energy from one substrate surface and release it to the substrate at the opposite side. The surface where heat energy is absorbed becomes cold, the opposite surface where heat energy is released becomes hot, as shown in figure (5). The typical maximum temperature difference between the hot side and the cold side of the (TEC), referred to $\Delta \mathrm{T}$ max, is around $70^{\circ} \mathrm{C}$. as recommended

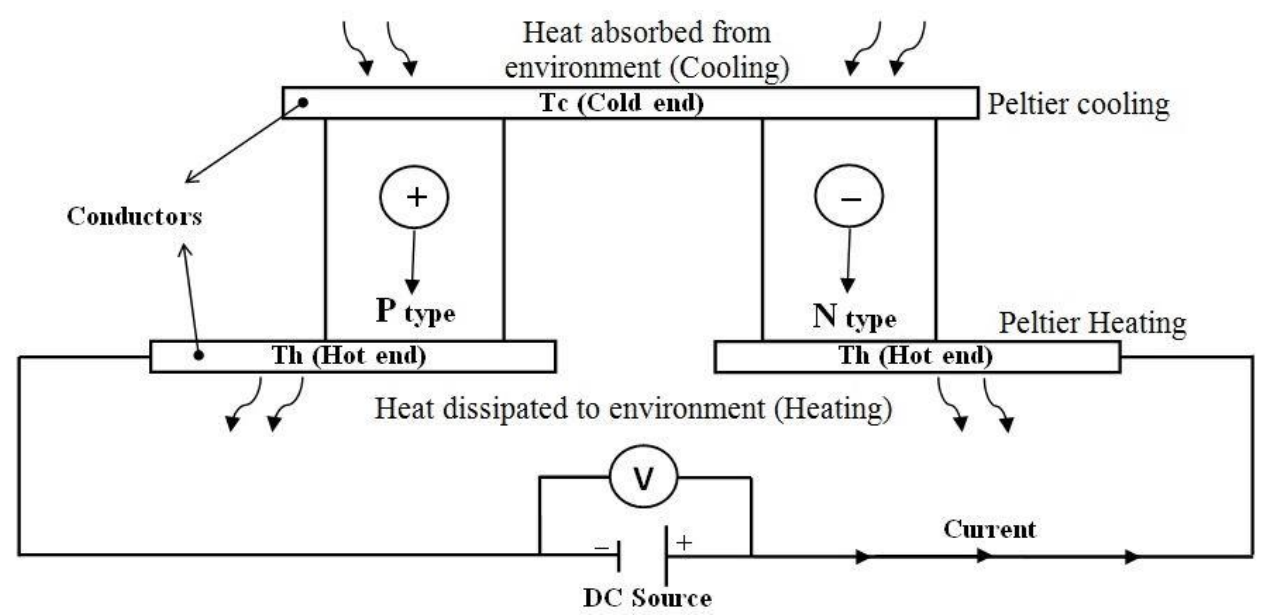

Fig. (5): Peltier theory

This thermo electric cooler works very well as long as removing the heat from hot side ( with a heat sink using fans). 
- If the electric current poles reversed, the peltier prototype can be used in the starting of engine work in coold areas, because in this case the water inside the peltier tank will be warmed which support fasting start engine.

\section{Peltier panels features in the experimental model:}

Peltier elements come in various forms and shapes. Typically, they consist of a larger amount of thermocouples arranged in rectangular form, and packaged between two thin ceramic plates; Two peltier sheets had been used in the experimental prototype, its geometric characteristics and features are shown in figures (6 A and B).
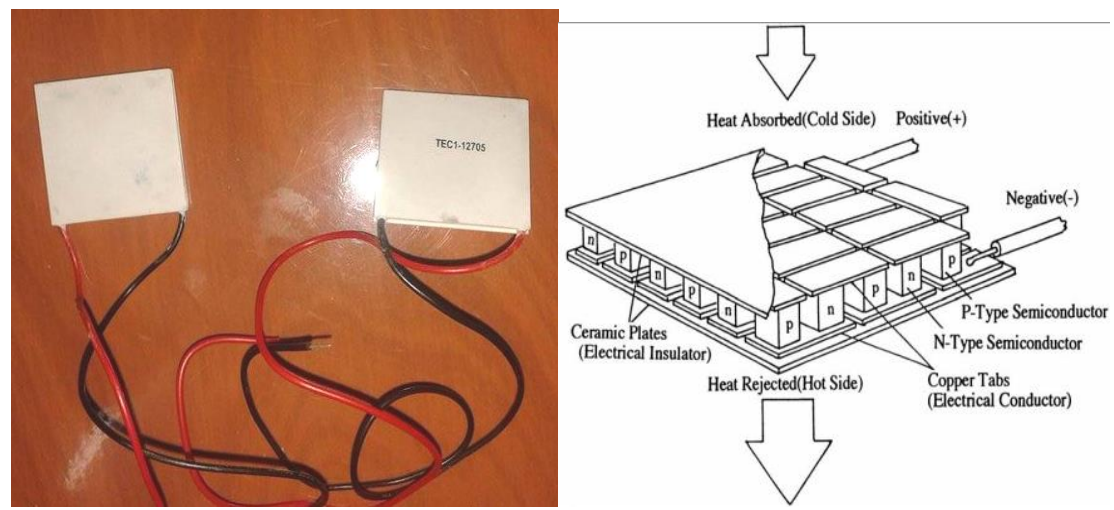

Fig. (6A): Experimental peltier panels
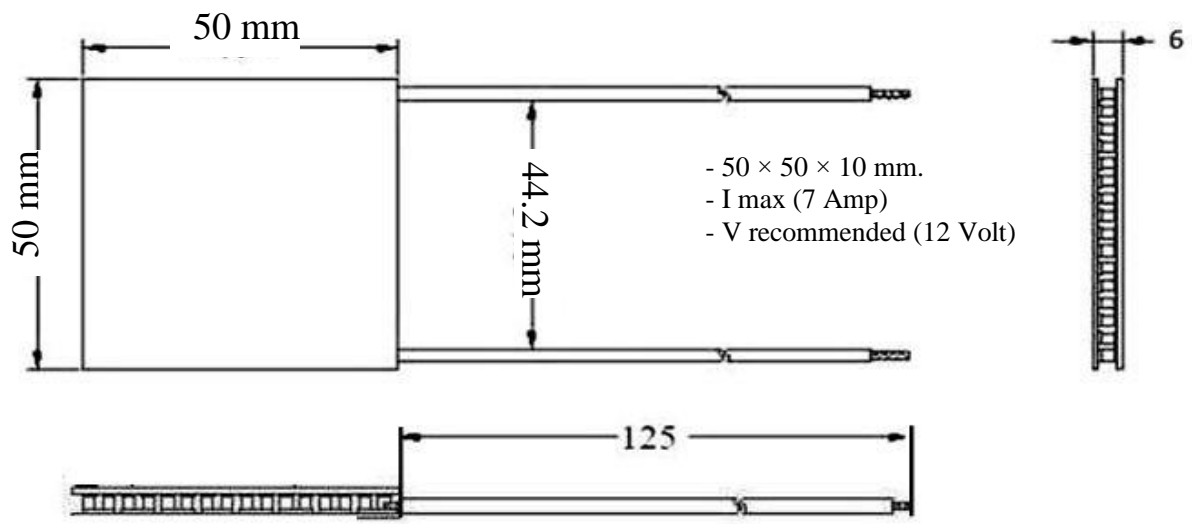

Fig. (6B): Geometric characteristics of the peltier panels

\section{Peltier panels concession}

1- High effective cooling and efficiency.

2- No moving parts, no noise and solid state.

3- Compact structure, small in size, light in weight.

4- Environmental friendly. 
5- Precise temperature control.

\section{Scope of experimental variables}

The main variables used in experiments were as follows:-

1- Five levels of electric current intensity $\left(\mathbf{C I}_{1}=1\right) \&\left(\mathbf{C I}_{2}=2\right) \&$ $\left(\mathbf{C I}_{3}=3\right) \&\left(\mathbf{C I}_{4}=4\right) \&\left(\mathbf{C I}_{5}=5\right)$ Ampere

2- Four levels of water flow rate $\left(\mathbf{F R}_{1}=0.5\right) \&\left(\mathbf{F R}_{2}=1\right) \&\left(\mathbf{F R}_{3}=1.5\right)$ \& $(\mathbf{F R} 4=2)$ liter/min.

3- Four levels of inlet water temperature $\left(\mathbf{W T}_{1}=75^{\circ}\right) \boldsymbol{\&}\left(\mathbf{W T}_{2}=80^{\circ}\right)$ $\boldsymbol{\&}\left(\mathbf{W T}_{3}=85^{\circ}\right) \&\left(\mathbf{W T}_{4}=90^{\circ}\right) \mathbf{C}$.

4- Two types of inlet water flow rate $\left(\mathbf{F} \mathbf{T}_{1}=\right.$ free flow $) \&\left(\mathbf{F T}_{2}=\right.$ in serpentine)

\section{RESULTS AND DISCUSSION}

\section{First type of inlet water flow rate $\mathrm{FT}_{1}$ (free flow)}

It can be seen from figures (7A through 7D) that, the influence of electric current intensity on quantity of absorbed heat (Q) appeared clearly with the highest values of water flow rate $(\mathrm{FR}=2 \mathrm{lit} / \mathrm{min}$.), but the data illustrated in all figures showed that the same values of heat absorbed with the lowest flow rate $(\mathrm{FR}=0.5 \mathrm{lit} / \mathrm{min})$ at the same inlet water temperature (WT).

From all figures (7A through 7D) it can be seen that, the same trend was also repeated at all inlet water temperature from $\left(\mathrm{WT}_{1}=75^{\circ} \mathrm{C}\right)$ to $\left(\mathrm{WT}_{4}=\right.$ $90^{\circ} \mathrm{C}$ ) under study.

On the other hand the data demonstrated in figures (7A through 7D) showed also direct relationship between water flow rate (FR), electric current intensity (CI) and inlet water temperature (WT) with the heat absorbed $(\mathrm{Q}=\mathrm{kJ} / \mathrm{min}$.), this direct relationships were obvious due to that all factors $\{(\mathrm{FR}),(\mathrm{CI})$ and (WT) $\}$ encourages heat transfer from water to the peltier sheet

Inspection of data demonstrated in figures (7A through 7D) showed that, increasing the electric current intensity from $\left(\mathrm{CI}_{1}=1\right.$ Ampere $)$ to $\left(\mathrm{CI}_{5}=5\right.$ Ampere) lead to an increase in the absorbed heat energy, the highest value of $(\mathrm{Q}=498 \mathrm{~kJ} / \mathrm{min})$ obtained with flow rate $\left(\mathrm{FR}_{4}=2\right.$ liter $\left./ \mathrm{min}\right)$ and inlet water temperature $\left(\mathrm{WT}_{1}=75^{\circ} \mathrm{C}\right)$ at electric current intensity $\left(\mathrm{CI}_{5}=5\right.$ Ampere). This due to increasing the efficiency of peltier sheets in cooling process with the highest value of intensity of electric current and the 
highest value of water flow rate which enable absorbing the highest quantity of absorbed energy.

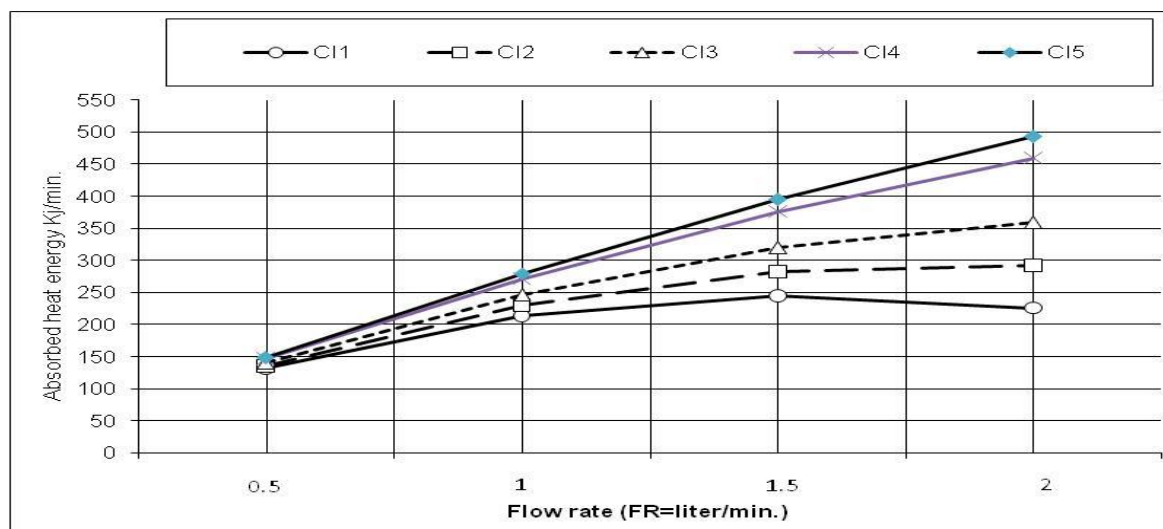

Figure. (7A): Absorbed heat energy $(Q=K j / \mathrm{min})$ at different flow rate (FR=liter $/ \mathrm{min})$ and electricity current intensity $(\mathrm{Cl}=A$ mpere) under study in the first water flow type (free flow) with (WT1=75 $\mathrm{C}$ )

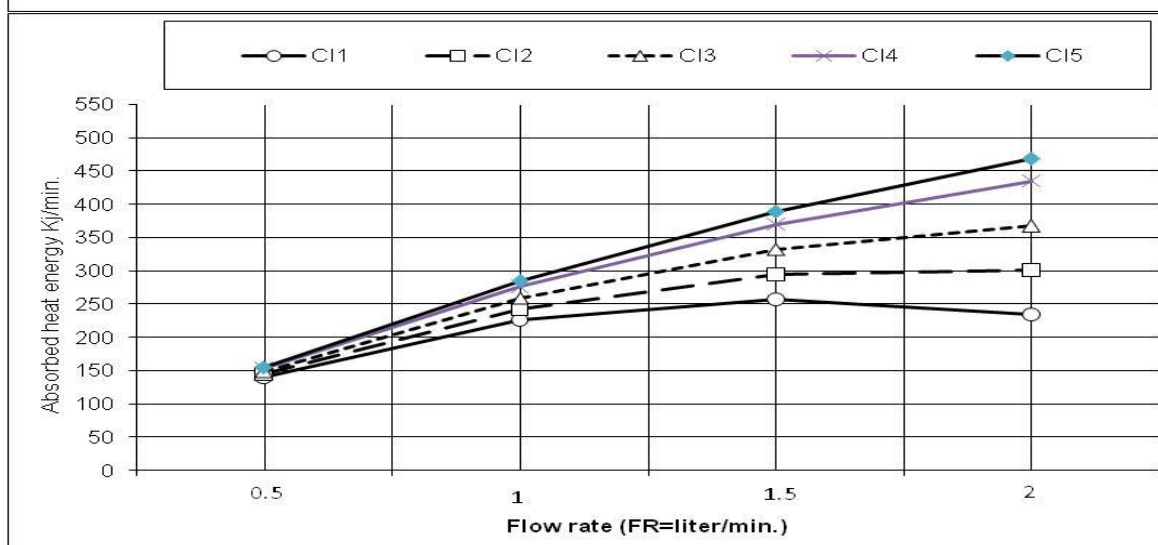

Figure. (7B): Absorbed heat energy $(Q=K j / \mathrm{min})$ at different flow rate (FR=liter $/ \mathrm{min}$ ) and electricity

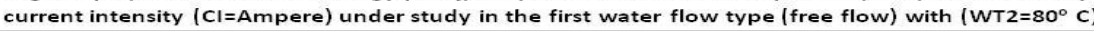

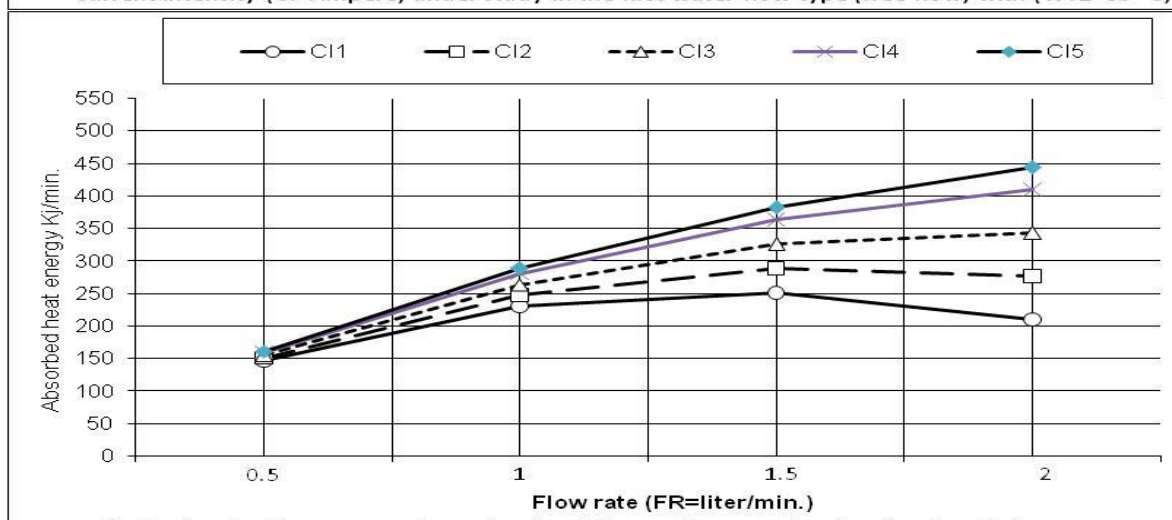

Figure. ( $7 \mathrm{C})$ : Absorbed heat energy $(\mathrm{Q}=\mathrm{Kj} / \mathrm{min})$ at different flow rate ( $\mathrm{F}=\mathrm{liter} / \mathrm{min}$ ) and electricity current

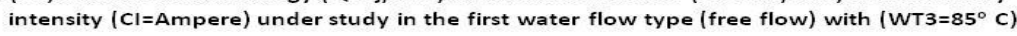




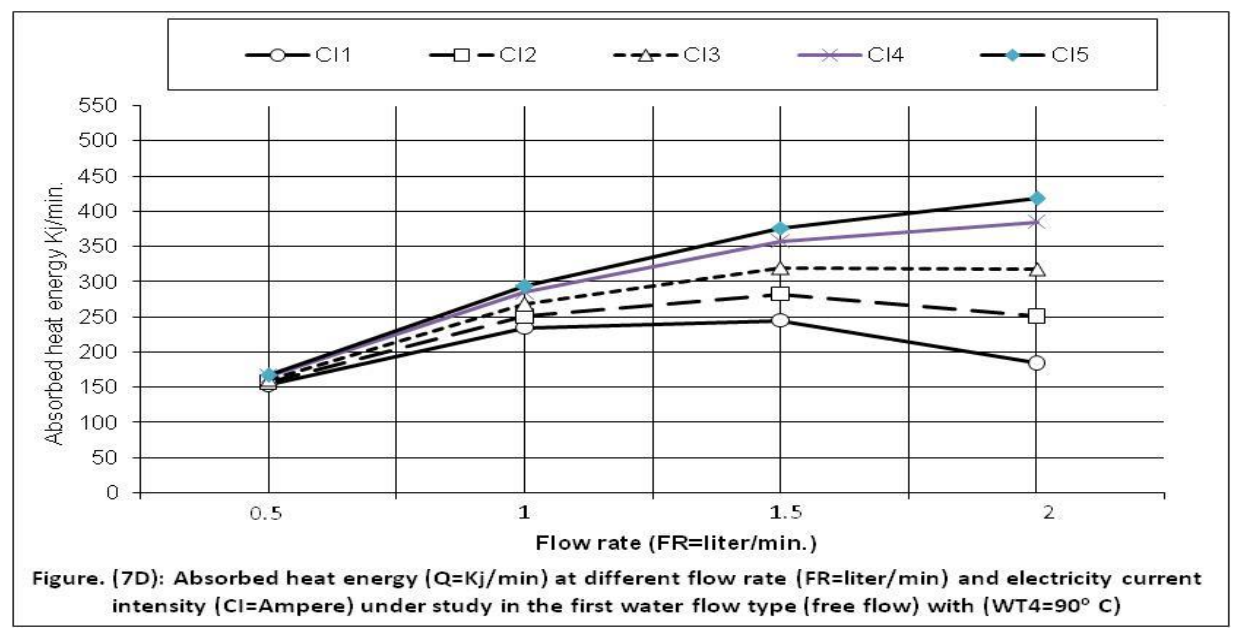

\section{Second type of inlet water flow rate $\mathrm{FT}_{2}$ (in serpentine)}

By inspection of data demonstrated in figures (8A through 8D) one can realize that, the water flow rate that more organized through the serpentine it causes more absorbed heat at all water flow rate under study compared with the $\mathrm{FT}_{1}$ (free flow). The water take more time to bath through the serpentine compared with free flow type. Therefore it can be seen that the absorbed heat effect of the electric current intensity (CI) at lower values of water flow rate $\left(\mathrm{FR}_{1}=0.5 \mathrm{lit} / \mathrm{min}\right.$.) inversed the trend in free flow. Also referring to figures $(8 \mathrm{~A}$ through $8 \mathrm{D})$ one can notice that, the highest value of absorbed heat $(\mathrm{Q}=502.2 \mathrm{Kj} / \mathrm{min})$ gained with $\left(\mathrm{CI}_{5}=\right.$ $5 \mathrm{amp}$.) and $\left(\mathrm{FR}_{4}=2 \mathrm{lit} / \mathrm{min}\right.$. $)$ with $\left(\mathrm{WT}_{1}=75^{\circ}\right)$ at serpentine type of flow water rate $\left(\mathrm{FT}_{2}\right)$.

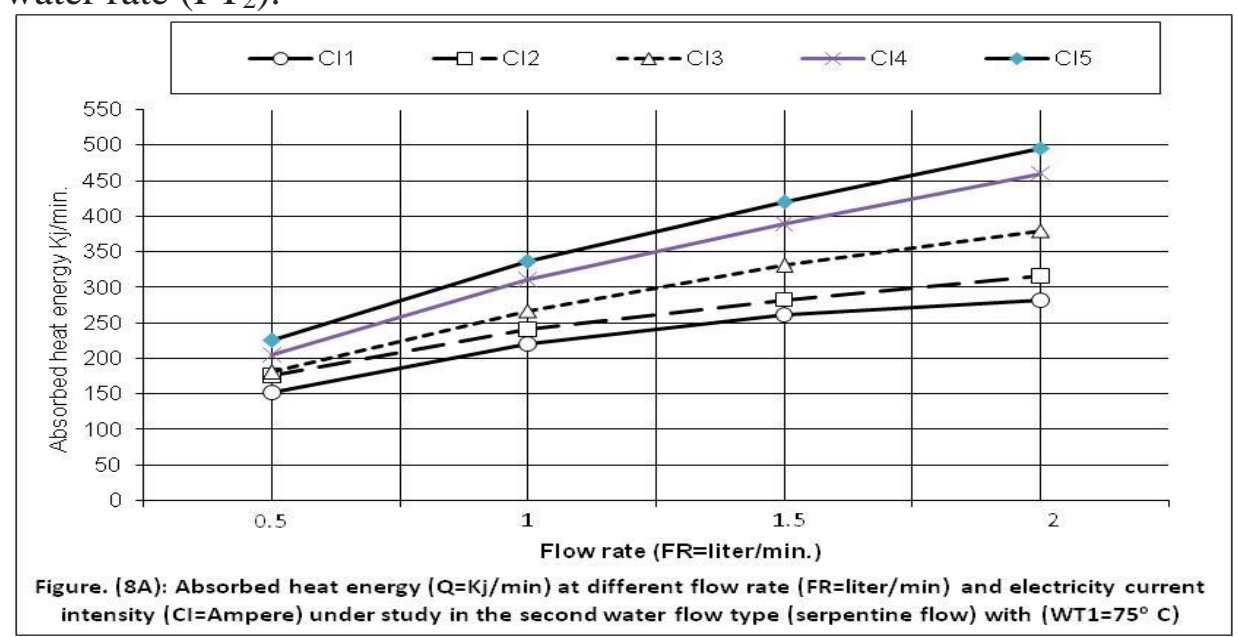




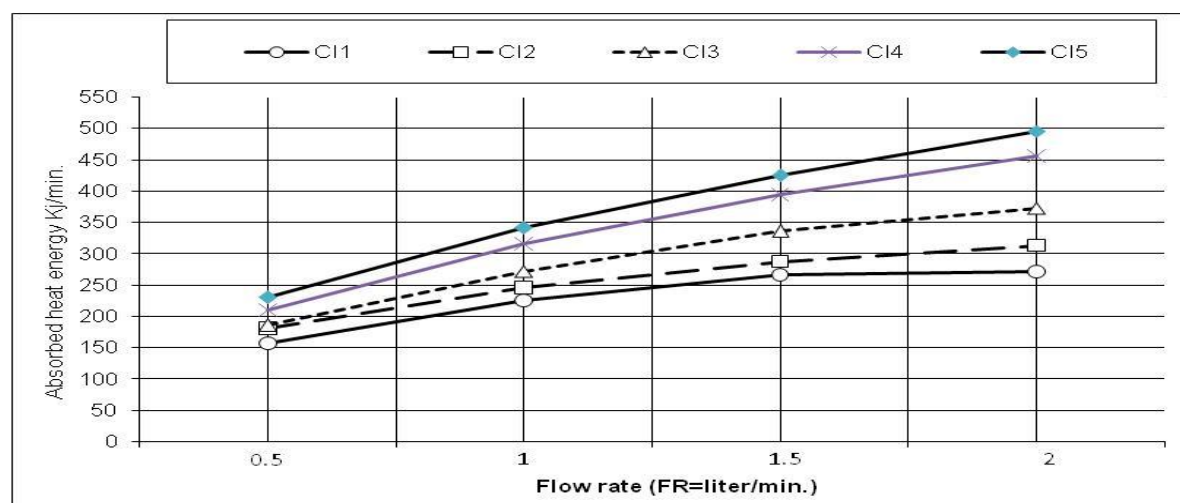

Figure. ( $8 B$ ): Absorbed heat energy $(Q=K j / \mathrm{min})$ at different flow rate (FR=liter $/ \mathrm{min}$ ) and electricity current intensity $(\mathrm{Cl}=$ Ampere) under study in the second water flow type (serpentine flow) with (WT2=80 $\mathrm{C}$ )

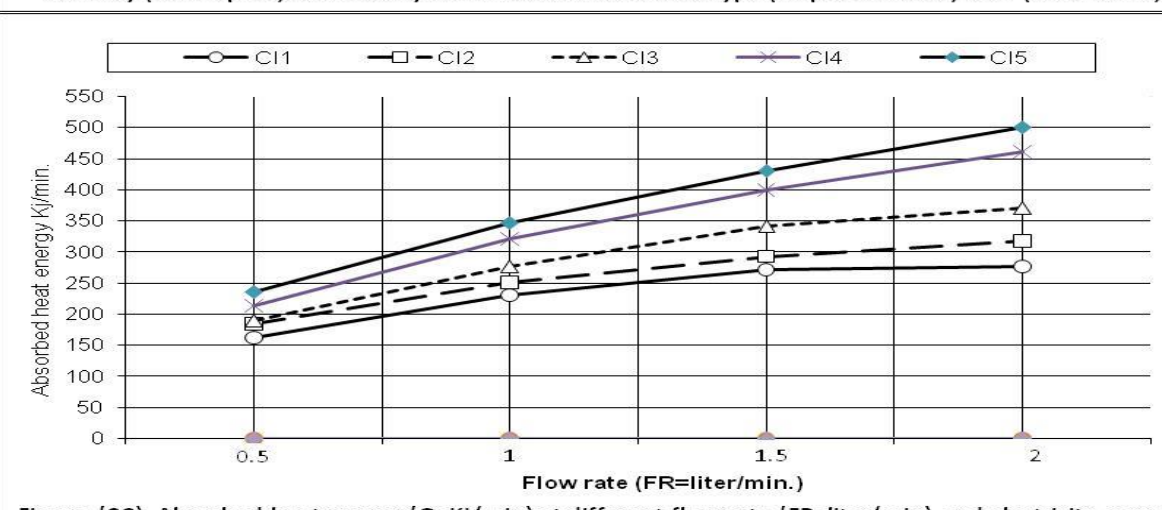

Figure. ( $\mathrm{BC}$ ): Absorbed heat energy $(\mathrm{Q}=\mathrm{Kj} / \mathrm{min})$ at different flow rate (FR=liter $/ \mathrm{min}$ ) and electricity current intensity $\left(\mathrm{Cl}=\right.$ Ampere) under study in the second water flow type (serpentine flow) with (WT3=85 ${ }^{\circ} \mathrm{C}$ )

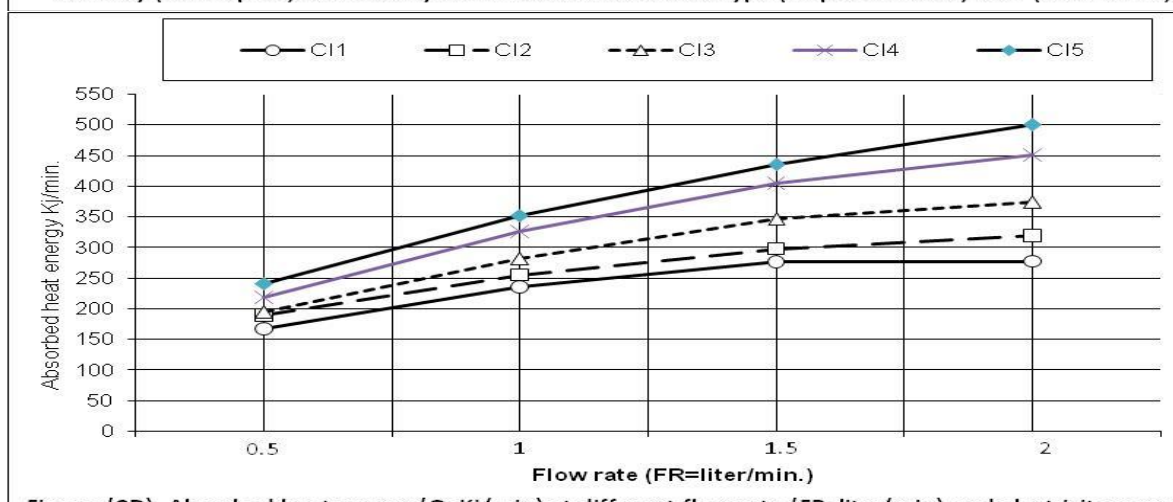

Figure. ( $\mathrm{SD}$ ): Absorbed heat energy $(\mathrm{Q}=\mathrm{Kj} / \mathrm{min})$ at different flow rate ( $\mathrm{F}=\mathrm{liter} / \mathrm{min}$ ) and electricity current intensity $\left(\mathrm{Cl}=\right.$ Ampere) under study in the second water flow type (serpentine flow) with (WT4=90 ${ }^{\circ} \mathrm{C}$ )

\section{REFERENCES}

Abdelghaffar, W. A.; M. N. Saeed; M. M. Osman and A. I. Abdelfattah (2002), Effects of coolant temperature on the performance and emissions of a diesel engine. pp. 187-197 (American Society of Mechanical Engineers, New York, NY 10016-5990, United States. 
Brace, C. J.; Burnham, H.; Wijetunge, R. S.; Vaughan, N. D.; Wright, K. and Blight, D. (2001), Integrated Cooling systems for Passenger vehicles, SAE Paper Number 2001-01-1248.

Chalgren, R. D. J. (2004), Thermal comfort and Engine warm up Optimization of a low flow advanced Thermal management system, SAE Paper Number 2001-01-0047.

Couetouse, H. and Gentile, D. (1992), Cooling System control in Automotive Engines, SAE Paper Number 920788.

Gogineni, P.; Gada, V. and Babu, S. (2014), Cooling systems in automobiles \& cars. International journal of advances in engineering \& technology (IJEAT) ISSN: 2249 - 8958, Volume-2, Issue-4, April 2013.

Heywood, J. (1988), Internal combustion engine fundamentals, New York, NY:McGraw-Hill.

Mirko, B. (2014), "Principles of heat transfer in internal combustion engines from a modeling stand point" $\mathrm{PhD}$ Thesis, Chalmers university of technology, Gothenburg-Sweden.

Pang, H. H. and Brace, C. J. (2004), Review of engine cooling technologies for modern engines. Proceedings of the Institution of Mechanical Engineers Part D-Journal of Automobile Engineering, 2004, 218(D11), 1209-1215.

Tonye, K. J.; Mohammed, M. and Fredy, H. (2013), A review of considerations in cooling systems calculations with variable coolant density and specific heat. International journal of advances in engineering \& technology. May (2013) Vol. 6, ISSN 1963 - 2231.

Wusner, Y.; Chen, B. and Hsieh, F. (2009), Heat transfer model for smallscale water cooled spark-ignition four-stroke engines. International Journal of heat and mass transfer, Vol. 52, pp. 1875-1886.

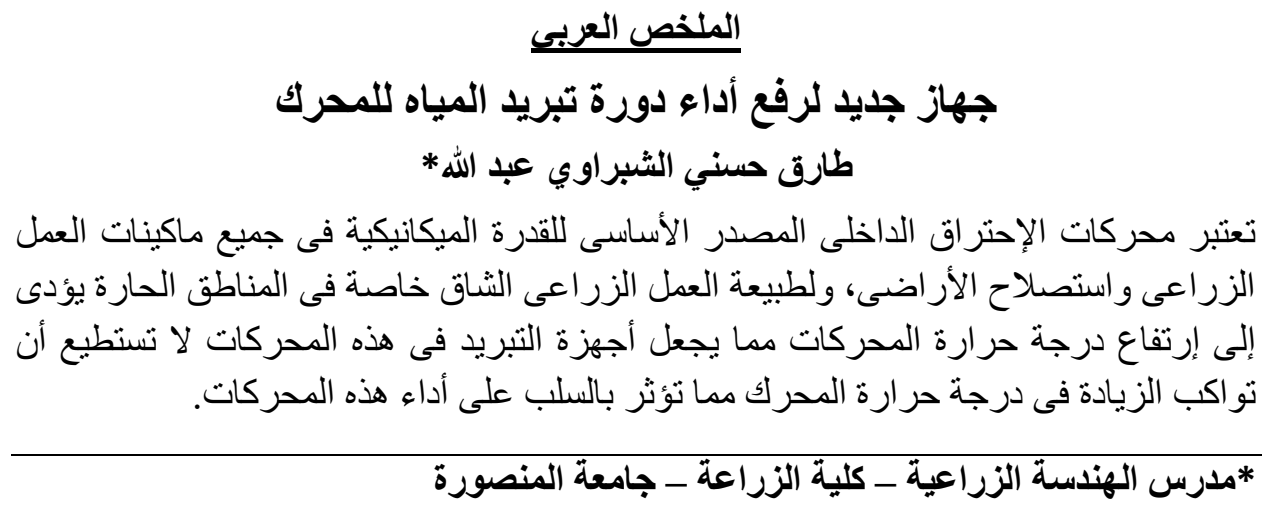


وقد تم تصنيع نموذج مصغر من وحدة التبريد المساعدة يحاكى النموذج الكبير المقترح تركيبه على دور ات التبريد فى محركات الكبيرة. أجريت تلك الدراسة بغرض تصنيع واختبار نموذج لوحدة تبريد مساعدة يمكن الحاقها بدورة

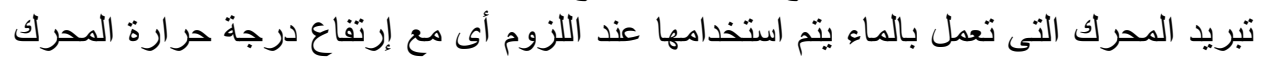
عن الحد المسموح به. فكانت الفكرة الأساسية تصنيع وحدة تبريد بسيطة سهلة التشغيل و لا تحتاج

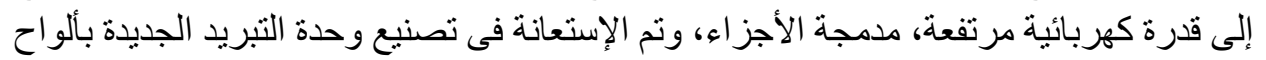

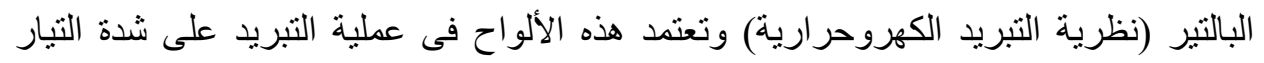

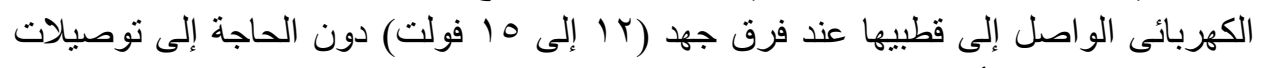

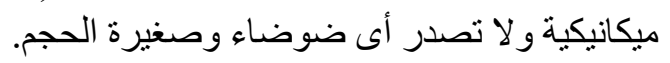

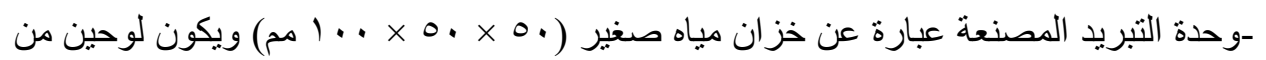

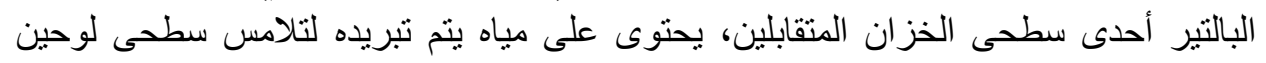

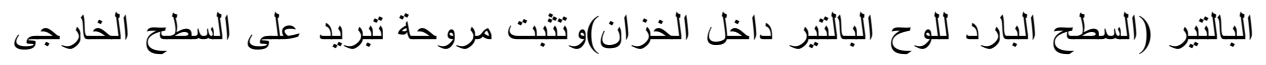

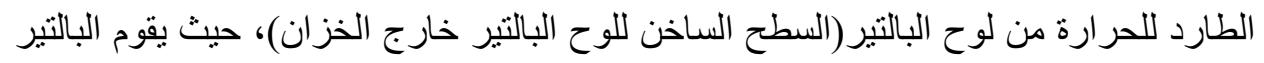
بنظرية التبريد على السطح الداخلى للخزان وطرد الحارة على السطح الخارجى والتى تقوم الته

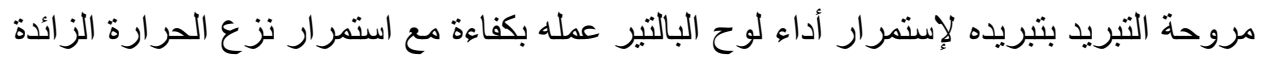

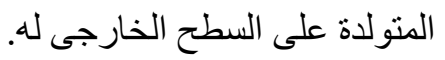
ولإختبار نموذج التبريد بالبالتير وكفاءة أداءه فى خفض دلى درجة الحرارة تم ذلك تحت عو امل

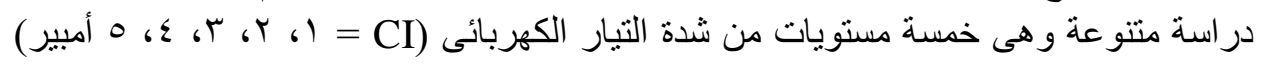

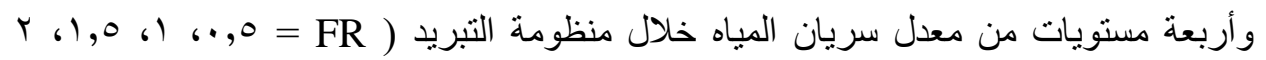

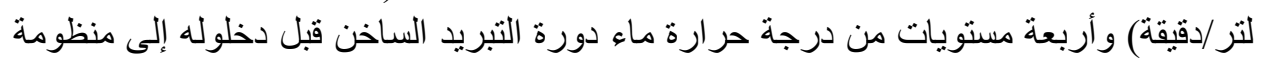

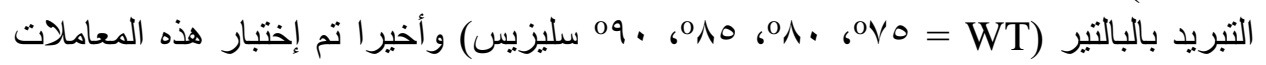

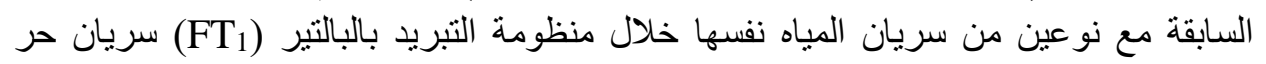
مباشر للمياه تقوم من خلاله المياه الساخنة مباشرة بملامسة (السطح البارد للوح البالتير داخل

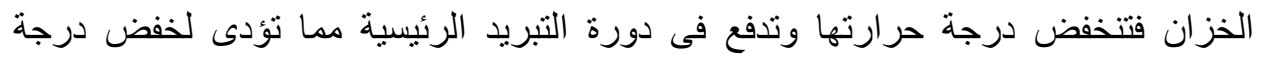

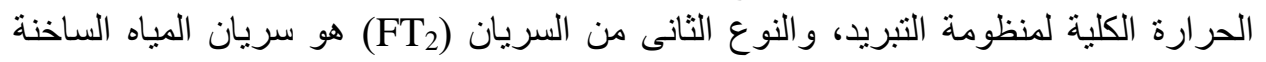

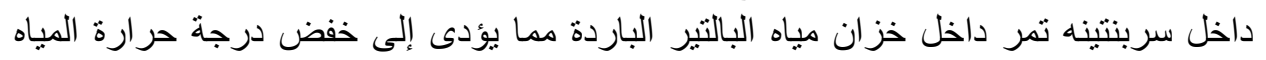

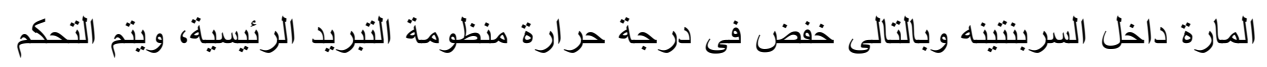

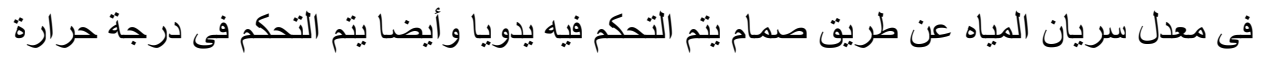

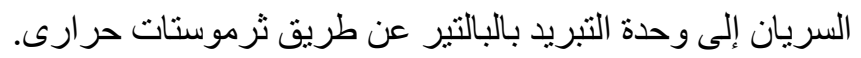
وتم قياس كمية الطاقة الحرارية الممتصة (Q كيلو جول/ دقيقة) مع كلا من المعاملات السابقة

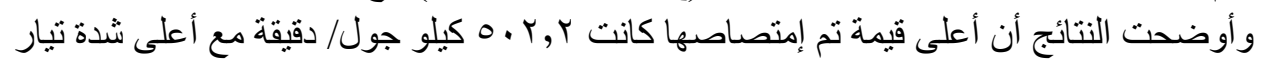

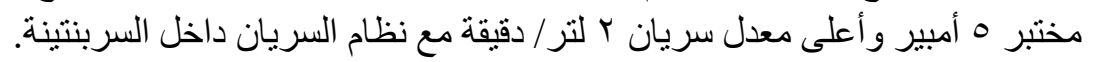

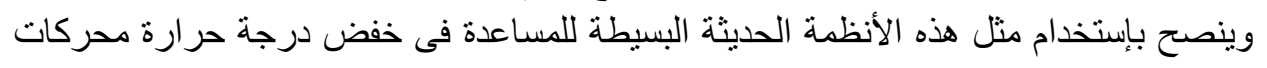

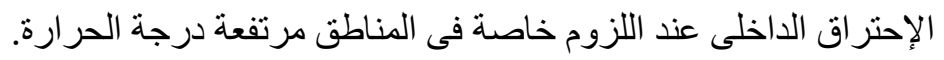

